\title{
Italian University Museums at Time of Covid-19 Lockdown: How to Restore a "Sense of Normalcy"
}

\author{
Michela Magliacani \\ University of Pavia \\ Daniela Sorrentino ( $\nabla$ daniela.sorrentino@unipv.it ) \\ University of Pavia
}

\section{Research Article}

Keywords: University Third Mission, COVID-19 lockdown, Italian university museums, university resilience, university public service, cultural knowledge transfer

Posted Date: August 6th, 2020

DOl: https://doi.org/10.21203/rs.3.rs-53886/v1

License: (1) This work is licensed under a Creative Commons Attribution 4.0 International License. Read Full License 


\section{Abstract}

The COVID-19 pandemic has had a dramatic impact on the normal conditions within which Higher Education systems are used to operate. This regards not only teaching and research, but also public engagement activities as a university Third Mission. As for the latter, there is scant literature on University Museums as subjects that transfer cultural knowledge to the community, so providing a relevant public service. Addressing this research gap, this study focuses on the critical Italian context, exploring how University Museums have responded to the COVID-19 lockdown. To this aim, the social science notion of resilience is adopted for interpreting the evidence on their ability to cope with the emergency. Data from legislative and statistical sources are complemented by a questionnaire administered to 34 University Museums. Findings show the ability of Italian University Museums to handle the ongoing emergency by carrying out digital and non-digital activities that prevent it to become worse. A conceptual model that highlights how University Museums contribute to transfer cultural knowledge also at a time of emergency is finally proposed.

\section{Introduction}

The COVID-19 emergency marked the life of the worldwide civil society, including businesses and public institutions. The unsuspected rapidity of SARS-Covid-2 diffusion has put a strain on healthcare, production, and education. The 5P (Prevention, Preparedness, Public Health, Political Leadership, People) referred to by the World Health Organization (WHO) in the COVID-19 pandemic declaration have been placed at the centre of the political choices made by the governments initially affected by the virus, such as Italy.

Though numerous studies have been carried out on the resilience of various economic sectors to this crisis, there is still little evidence on this respect (Rapaccini et al., 2020). As far as universities are concerned, interdisciplinary literature has so far focused on the impact of digital migration of teaching and research. Regarding the Third Mission, despite the persistent debate on the approximate contents included in this concept, there are scant investigations at the international level. The debate has been concentrated on the university's ability to generate profit through technology transfer, the creation of spinoffs, academic start-ups and patents (Barker, 2015), as well as in relation to the uneasy and discussed assessment of academic institutional activities for rewarding purpose (Veltri \& Puntillo, 2020). Given the pandemic impact on universities and places of culture, addressing that literature gap is of great interest for both academics and practitioners. Scholars have been concerned on understanding of how the pandemic has impacted the models of Higher Education (HE henceforth) management and university engagement in the face of anti-COVID measures that have changed users' habits, imposing new forms of academic and cultural learning (Agostino et al., 2020; Watermeyer et al., 2020). Those contributions provide insights for extending knowledge on what happened during the lockdown in the various contexts to compare experiences of resilience and forecast scenarios. Their evidence should be useful for policy 
makers to achieve greater awareness of the impacts of the choices made and plan future ones, with the aim of improving post- COVID conditions for a gradual and safe return to the normalcy.

This study therefore focuses on the Third Mission of HE system, with specific regard to the related museum management. Particularly, this research aims at shedding a light on the resilience ability of University Museums (UMs) during the lockdown, that is the first measure adopted to cope with the COVID -19. The context chosen is Italy, considered a critical case both in relation to the historical- scientific heritage managed by universities, and for the dramatic level of spread reached by the virus in this country after China. From this reasoning, a specific research question arises:

How have Italian Universities responded to the COVID-19 lockdown in relation to the UMs management?

To address this research question, this study administers a questionnaire to 34 Italian UMs', thus exploring the activities they have been carrying out during the lockdown.

The contribution of the research is threefold. Firstly, this study fulfils the literature gap on UMs, by demonstrating their significant contribution to the development of the Third Mission within the HE system also in the face of the COVID -19 emergency. Additionally, it increases the understanding of the concept of resilience in $\mathrm{HE}$, so far studied in the perspective of students, rather than from the side of the institution. Consequently, the research proposes a model of UMs' resilience, which stems on bridging the literature on HE Third Mission and emergency management. Thus, the model suggests useful insights to UMs' policy makers and managers not only in the face of pandemic emergencies, but also with respect to external disturbances, concerning the life of the institution itself.

This study is structured as follows. Next section provides the literature review on the Third Mission of HE systems, as well as on the resilience conceptualization in social science. Section 3 describes the research methodology, detailing the research design, data collection, and data analysis methods. Section 4 presents the research results, while Section 5 provides a discussion that leads to a UMs resilience conceptual model. Finally, Section 6 highlights the concluding remarks of the study.

\section{Methods}

\section{Literature Review}

\section{The Third Mission of Universities: from academic citizenship to the museum management}

The interdisciplinary debate on the civic mission of the University has been developing since the late 20th Century. Accordingly, the literature on HE acknowledges "service", together with teaching and research, as one of the three traditional purposes of the university around the world (Cummings, 1998; Macfarlane, 2007). To shed light on the activities carried out by academics within and outside the organizational boundaries of the university - the so-called academic citizenship - Macfarlane (2007: 265) introduced the "service pyramid" model (Figure 1). At the base of the latter (Student service), there are all the 
activities concerning the students' caring (student counsellor, coaching, mentoring, etc.). In the case of collegiate students, the services in terms of tutoring and, generally, of educational developments are posed at the second level of the pyramid (Collegial service). Moving up to the third one, there are activities carried out by academic as members of either university bodies or internal and external committees (Institutional service). Research related work and collaborations directed at developing the discipline (e.g., academic journal reviews or editorial membership), or at updating the professional boards (e.g., practitioners' training, professional bars' assessments) are embedded in the fourth level of this model (Discipline based and professional service). Last but not least, activities relating to develop educational links with communities members' (e.g., medias, governments, businesses) and organizations through knowledge transfer (e.g., spin-offs, start-ups, patents, cultural initiatives, research partnerships and fundraising) are posed at the top of service pyramid (Public service).

Building on this model, numerous pieces of research have stressed the scarce relevance assigned to the academic citizenship activities, although they boost the universities to leave their ivory tower (B. Martin \& Etzkowitz, 2000) and enable them to meet the social, economic as well as cultural needs of communities (Sataøen, 2018). Therefore, the debate has been focusing on how to assess and reward service activities by academics to encourage them to the advantage of students, collegiate, professionals and civil society (Barker, 2015; Nicolo' et al., 2020; Tagliaventi et al., 2019). Some scholars have referred to the broad concept of university engagement by investigating the service activities by individual academics (Knudsen et al., 2019). Nevertheless, most of the efforts have been addressed to those that generate profit through technology transfer based on the STEM (Science, Technology, Engineering, Mathematics) disciplines (Wright \& Shore, 2017), as academics are increasingly required to collect funds for their research.

Emphasising the relational perspective, the university, as a knowledge hub for engagement, can bridge academic environment and relevant outside industrial and societal actors (Geuna \& Muscio, 2009; Perkmann et al., 2013). Hence, public engagement has been considered as a university Third Mission. The meaning of this term (Third Mission) is still controversial, because of its different interpretation by the HE systems. According to the mainstream research, the "Third Mission" is a silent concept used for describing diverse activities based on public engagement. It embeds a multi- dimensional approach (Knudsen et al., 2019), because its focus is not only the profit generation (such as by selling the intellectual property rights or creating spin-offs and start-ups), but also the generation of public value and societal impact (Bozeman, 2000; Bozeman et al., 2013).

However, little has been investigated about the other university engagement activities, which enable nonSTEM subjects to transfer cultural and creative knowledge towards community with a large societal rather than economic impact. The knowledge intensive activities encompass museums and other cultural institutions that can improve the quality of life and, meanwhile, harness the creativity economy, considering the service they provide to the community (Moreton, 2018). The UMs' contribution to the development of the Third Mission of the HE is still unexplored (Martino, 2016). A recent study has highlighted the challenge of the universities to preserve, promote and enhance their cultural heritage 
under the sustainable perspective (Mozzoni et al., 2018). The relationship between the two-core missions - teaching and research - and the UMs is less investigating, even though it has potentiality to boost the public engagement and the knowledge transfer in the creativity economy. Additionally, the UMs' capability to create value for money, against the scarce public funds available to the HE also for this cultural heritage management, deserves more attention (Colasanti et al., 2018). The literature gaps aforementioned have stimulated the interest to extend the knowledge on the universities' Third Mission, with particular regard to the public service, provided by managing their cultural heritage.

\section{Resilience in social science: a key notion for emergency management studies}

Though people and organizations have been chronically demanded to cope with external shocks and crises of different nature, things such as the globalization have contributed to increase the pace of their diffusion throughout the world, thus highlighting their severity (Comfort et al., 2020; Fligstein \& Habinek, 2014). Hence, the current global scenario is featured by recurring and sudden shocks - such as fiscal and financial crises, natural disasters, pandemics, and terroristic attacks - likely to produce dramatic implications on the social, economic, and political levels (Bundy et al., 2017).

As public sector organizations are particularly exposed to such shocks, "resilience" - broadly meant as a strategy adopted to respond to critical and emergency situations - has gained an unprecedented attention in the public policy and management studies in the last decades (Duit, 2016; Sciulli et al., 2015). By borrowing this term from other research fields, scholars of these disciplines are adding significant knowledge to studies on resilience, enriching its understanding from both a conceptual and empirical level (Comfort et al., 2010; Conz \& Magnani, 2020). As for the former, "resilience" does not represent a typical and exclusive social science notion, whereby efforts have been made to shape it for social sciences purposes. As illustrated by Alexander (2013) in a historical analysis on the etymology of the term "resilience", it represents a multi-faceted one, the meaning of which has been largely affected by linguistic contaminations and scientific conjugations. Originating from the Latin verb resilio, reisilire (i.e., bouncing back), its use in the scientific field can be tracked back to the 15th century - as testified by Francis Bacon's manuscripts of that time - whereas it is only from the 19th century that is gains a popularity and is adopted in disciplines such as psychology, mechanics, and ecology. Since the mid-20th century, resilience has been finally welcomed by social scientists, promoting a shift of the analytical focus from the individual or technical perspective to the social systems one (Gibson \& Tarrant, 2010; Labaka et al., 2016). Coherently, the several definitions of resilience proposed by social scientists have all turned around two fundamental dimensions (Boin \& van Eeten, 2013): 1) the occurrence of a surprising sudden external disturbance that impacts a given social system, and 2) the ability of that social system to restore or recover a state of normality (Bruijne et al., 2010; Comfort et al., 2010; Linnenluecke \& Griffiths, 2010; Wildavsky, 1988) Whereas scholars unanimously consider the "occurring disturbance" as an external one - that is one out of the scope of disturbances that the social system is designed to manage - there is much more debate on what constitutes the "resilient ability" of social systems. Divergencies on this side have led to identify two distinct types of resilience, which are: 
1. Precursor resilience, referred to as the social systems' ability to absorb external shocks gracefully (Foster, 1993), that is "monitoring and keeping operations within a bandwidth of conditions" while implementing actions to restore those conditions as much rapidly as possible (Pettersen \& Schulman, 2019, p. 461);

2. Recovery resilience, denoting the social systems' ability to respond to external unexpected disorders by "bouncing back to a state of normalcy" (Boin \& van Eeten, 2013, 431).

Thus, while precursor resilience regards the capability of the system to handle an ongoing disturbance and prevent it from becoming worse, recovery resilience instils the idea of learning from the unexpected disturbance and emerging stronger than before as a social system (Duit, 2016).

On the empirical level, the efforts made on the conceptual one enable social scientists to operationalize the resilience notion, that is to "climb down" to the experiential level (C. R. Martin, 2015). Precisely, the described notion of resilience has assisted social scientists in studying how people and organizations cope with serious external shocks, shedding a light on those organizational features and processes playing a role in responding to external disturbances (Comfort et al., 2010; Linnenluecke \& Griffiths, 2010). Hence, it is not surprising that resilience has increasingly inhabited the literature on emergency and disaster management ( Conz \& Magnani, 2020; Hu et al., 2014; Noordegraaf \& Newman, 2011; Teng-Calleja et al., 2020), including those investigations specifically concerning the current COVID-19 pandemic as a peculiar instance of external shock (Entress et al., 2020; Jing, 2020).

Such focus on resilience has regarded also HE studies. Nevertheless, the resilience notion has been conjugated mainly at the individual level to explain students withdrawal or retention (Cotton et al., 2017; Walker et al., 2006; Wellington et al., 2005). At the same time, the current COVID-19 pandemic has been emerging as a serious external disturbance that has hit HE organizations for their whole set of services - encompassing the Third Mission - thus stimulating a forthcoming debate on their responses in this respect (Watermeyer et al., 2020).

Aiming at exploring how Italian HE systems have responded to the COVID-19 lockdown in relation to the UMs management, this paper welcomes the opportunity to resort to the social science notion of resilience. Conceiving the COVID-19 as a serious external disturbance, this allows supporting the exploration of Italian UMs' response to the COVID-19 by focusing on their ability to either restore or recover a state of normalcy during the lockdown.

\section{Research methodology}

The methodology of this paper builds on an interpretative approach and relies on a desk research strategy. As for the units of analysis, the research focuses on Italian public universities. According to what explained above, public sector organizations are those most exposed by external disturbances 
such as pandemics, thing that justifies a greater attention on them in the emergency management literature (Duit, 2016; Sciulli et al., 2015). With particular regard to universities, public ones are those that have been most severely affected by the austerity measures that make the pursuing of their strategies difficult by meeting public budget constraints (Nicolo' et al., 2020; Parker, 2011). The Italian Ministry of Education, Research and Higher Education provides an online and open data platform, where metadata on the HE system are reported. There, a comprehensive dataset containing the list and major information on universities is published (http://dati.ustat.miur.it/dataset/metadati). As shown in that database, in Italy there are 78 universities, among which 58 are public and 20 privates. Considering only the public ones, an extensive online research led to identify $38 \mathrm{UMs}$, which were not scheduled in any extant database.

Aiming at collecting data on Italian UMs response to the COVID-19 lockdown, two sources of information have been used. First, legislative documents issued by the Italian Government during the COVID-19 emergency and statistical description of the pandemic diffusion have been gathered from the related digital platforms. Second, information from the inside of the UMs were needed as they were not available elsewhere. Therefore, a questionnaire was designed and sent to either the President, Director or Curator of each UM. To design it properly, a pilot version of the questionnaire was administered to three UMs (representing the $9.8 \%$ of the sample). This allowed to verify whether questions were put clearly, as well as whether additional alternatives should have been included in the multiple-choice answers. The final version of the questionnaire has been composed of 10 questions, articulated into four sections: the former asked for UMs' demographics (e.g., organizational model, size, opening hours, ticketing); sections II and III were respectively concerned on which activities UMs were used to perform before the lockdown and which ones they have been carrying out during the lockdown itself; section IV includes a final question on the role of culture during the lockdown (Table 1). All questions were formulated as multiple-choice answers, except for the final one that let respondents free to provide a personal textual comment. Though not directly related to the research question of this paper, it was assumed that the way respondents perceived community's attitude towards culture during the lockdown would have enriched the understanding of UMs' response to that disturbance. The questionnaire has been sent to $38 \mathrm{UMs}, 34$ of which have provided an answer through a digital platform, thus ensuring $91.2 \%$ of response rate. As such, the analysed sample is represented by those $34 \mathrm{UMs}$ responding to the questionnaire. Data were collected between May and June 2020.

Table 1. Data collection design 


\begin{tabular}{|c|c|c|}
\hline $\begin{array}{l}\text { Questionnaire } \\
\text { sections }\end{array}$ & Questions & Contribution to the research aim: data on... \\
\hline \multirow[t]{5}{*}{ Section I } & 1. Role of respondent & \multirow{5}{*}{$\begin{array}{l}\text { How UMs are managed by Italian universities } \\
\text { within their Third Mission }\end{array}$} \\
\hline & $\begin{array}{l}\text { 2. UM } \\
\text { organizational model }\end{array}$ & \\
\hline & $\begin{array}{l}\text { 3. UM size (no. of } \\
\text { staff units) }\end{array}$ & \\
\hline & 4. Opening hours & \\
\hline & 5. Ticketing & \\
\hline Section II & 6. Pre-lockdown activities & $\begin{array}{l}\text { Which activities Italian UMs were used to carry } \\
\text { out before the lockdown to enhance the } \\
\text { universities' public engagement }\end{array}$ \\
\hline \multirow[t]{3}{*}{ Section III } & $\begin{array}{l}\text { 7. Whether activities } \\
\text { have been carried out } \\
\text { during the lockdown }\end{array}$ & \multirow[t]{2}{*}{$\begin{array}{l}\text { Whether and how Italian UMs have responded } \\
\text { to the lockdown }\end{array}$} \\
\hline & $\begin{array}{l}\text { 8. If so, which activities } \\
\text { have been carried out } \\
\text { during the lockdown }\end{array}$ & \\
\hline & $\begin{array}{l}\text { 9. Whether ICTs } \\
\text { investments have } \\
\text { been made during } \\
\text { the lockdown }\end{array}$ & $\begin{array}{l}\text { Which kind of technological efforts have been put in } \\
\text { place during the lockdown }\end{array}$ \\
\hline Section IV & $\begin{array}{l}\text { 10. Role of culture during } \\
\text { the lockdown (open) }\end{array}$ & $\begin{array}{l}\text { Whether the COVID- } 19 \text { pandemic is perceived to } \\
\text { have increased the role of culture for the society }\end{array}$ \\
\hline
\end{tabular}

As for the data analysis, answers to the questionnaires have been coded as binary variables and thus treated as quantitative data, with the exception of the last open answer. Data were analysed following a constructivist approach based on the interpretation of reality as a social construction (Englund et al., 2011; Giddens, 1981). This was enabled by an in-depth analysis of the research background, to enhance the understanding of a complex phenomenon (Yin, 2017). Practically, the analysis of the data gathered has been performed by making a comparison between UMs activities before and during the lockdown. Indeed, analysing whether and how UMs have been carrying out their activities during the lockdown enables assessing their resilience ability with respect to the COVID-19 disturbance.

\section{Results}

\section{Findings}

\section{Research background}

Everything seemed so far away, a constant news, but little more than a chronicle of the numerous cases that have grown every day in Wuhan since December 31st, 2019. Lockdown was heard for the first time 
on January 23rd, 2020, with the cancellation of the Chinese New Year due to the rapid spread of the 2019n COVID family of Coronavirus. Already before, to be precise, on January 14th, the first case of infection occurred in Thailand, then in South Korea and Japan. On January 31st, two positive cases in Italy, these were two Chinese tourists, treated by the INMI Lazzaro Spallanzani, national centre for severe acute respiratory syndrome like SARS. On February 11th, WHO declared the change of the virus name in SARSCov-2 and names the disease COVID -19, from the acronym Co (Corona), Vi (Virus), D (Desease) and 19 (the year of virus identification). Shortly thereafter, the case of patient 1 of Codogno (Lodi, Lombardy, Northern Italy) was announced. Hence, the dizzying increase of this disease (after 3 days from patient 1 , the cases have increased to 655 with a percentage of $27.42 \%$ of deaths) has marked a historic change in the life of Italians, with dramatic effects on the society and the economy globally.

The Italian Prime Minister's Decree (DPCM) on February 23rd declared Lombardy "red zone", which meant the adoption of restrictive measures like in Wuhan. Precisely, the legislation provides numerous limitations for that area, ranging from the prohibition to move from home, the closure of museums and other cultural institutes and places (art. 1, letter e), to the suspension of production and educational activities, except for the distance learning and smart working (art. 1, letter d). Meanwhile, the number of infected and deaths achieved dramatic peaks especially in Lombardy, though the virus did not spare other Italian regions, especially in the North (Figure 2).

The Italian conditions imposed to extend the lockdown throughout the national territory, as sanctioned by the DPCM dated March 11th. On the same day, the WHO General Director declared the state of pandemic worldwide, using the following words:

We have therefore made the assessment that COVID-19 can be characterized as a pandemic. [...] We have never before seen a pandemic sparked by a coronavirus. This is the first pandemic caused by a coronavirus.

Of the 118,000 cases reported globally in 114 countries, more than 90 percent of cases are in just four countries, and two of those - China and the Republic of Korea

- have significantly declining epidemics.

We are grateful for the measures being taken in Iran, Italy and the Republic of Korea to slow the virus and control their epidemics. We know that these measures are taking a heavy toll on societies and economies, just as they did in China.

All countries must strike a fine balance between protecting health, minimizing economic and social disruption, and respecting human rights. This is not just a public health crisis, it is a crisis that will touch every sector - so every sector and every individual must be involved in the fight. I have said from the beginning that countries must take a whole-of-government, whole-of-society approach, built around a comprehensive strategy to prevent infections, save lives and minimize impact (Source: 
https://www.who.int/dg/speeches/detail/who-director-general-s-opening- remarks-at-the-media-briefingon-covid-19, 11-march-2020).

54 days later, recording a first drop with a daily decrease of 20 cases for a total of 108.237 positives, the Italian Prime Minister's Office proclaimed the end of the lockdown, consisting of a gradual recovery of production, which nevertheless excluded the education and museum ones. The Decree on May 4th declared the beginning of phase 2 , that is the coexistence with the COVID-19. The decreasing trend of the epidemic curve enabled to restart many other activities, including those of museums, that reopen since May 18th in compliance with the distance and anti-COVID-19 security measures (DPCM May 17th, 2020, art 1, letter $p$ ). The same rules kept university teaching at distance, with the exception of laboratories and medical specialties (DPCM May 17th, 2020, art 1, letter s).

The time span taken into consideration by the questionnaire is the lockdown phase, during which human operations took place only digitally (Figure 3 ).

Recent studies have examined the impact of the COVID-19 emergency in universities, particularly on teaching, which is the most affected by the precautionary measures imposed by the governments of the States most affected by the pandemic. Precisely, the research carried out by Watermeyer et al. (2020) in the Universities of the United Kingdom showed a dual reaction to the online migration by the academic body: "afflictions" for the competitiveness, sustainability within a global student market and, to a lesser extent, "affordances" in terms of accelerated pedagogical modernization on the level of social connectivity and inclusivity. The same study suggests extending the observation to other university contexts at an international level, as well as enlarging the object of research on the pedagogical dimension of technology (Watermeyer et al., 2020). As for other university public engagement, nothing has yet been written on the period considered. With regard to museums, on the other hand, cultural heritage literature provides insights into the first-hand experience of the impact of the pandemic on worldfamous ones, from the Getty Museum in Los Angeles (Potts, 2020) to the Groniger Museum in Holland (Blühm, 2020), and the China Science and Technology Museum in Beijing (Ou, 2020). The major Italian state museums have not been left behind, resorting to technology to keep their relationship with the audience, through the use of social media, which has obviously doubled with the proposal of digital content on the works on display in addition to interactive cultural initiatives. The research leads to rethink how museums carry out their activities in light of the feedback collected from social networks (Agostino et al., 2020).

\section{Results from the questionnaire}

Responses to Section I of the questionnaire enable to gain an overall picture on the respondents' demographics (Table 2).

Table 2. Respondents' demographics 


\begin{tabular}{|c|c|c|c|}
\hline Variable & Category & $\mathrm{n}$ & $\%$ \\
\hline \multirow[t]{3}{*}{ Location } & North & 8 & 23.5 \\
\hline & Centre & 10 & 29.4 \\
\hline & South & 16 & 47.1 \\
\hline \multirow[t]{5}{*}{ Organizational model } & Cost centre & 17 & 50 \\
\hline & Service centre & 4 & 11.8 \\
\hline & Foundation & 1 & 2.9 \\
\hline & Central administration unit & 8 & 23.5 \\
\hline & Department unit & 4 & 11.8 \\
\hline \multirow[t]{5}{*}{ Size (staff units no.) } & $\leq 3$ & 14 & 41.2 \\
\hline & $4-6$ & 4 & 11.8 \\
\hline & $7-10$ & 2 & 5.9 \\
\hline & $10-20$ & 7 & 20.6 \\
\hline & $\geq 20$ & 7 & 20.6 \\
\hline \multirow[t]{5}{*}{ Opening hours } & Always & 7 & 20.6 \\
\hline & 2 days/week & 1 & 2.9 \\
\hline & Office hours & 17 & 50 \\
\hline & By appointment & 5 & 14.5 \\
\hline & Flexible & 4 & 11.8 \\
\hline \multirow[t]{3}{*}{ Accessibility } & Free access & 4 & 11.8 \\
\hline & Fee entrance & 9 & 26.5 \\
\hline & Diversified fee entrance & 21 & 61.8 \\
\hline
\end{tabular}

Among the 34 UMs analysed, almost half of them are located in Southern Italy (47.1\%), while the remainder is distributed in the Northern (23.5\%) and the Central $(29.4 \%)$ regions of the country. As for the way through which they are managed, results reveal the presence of five different organizational models, featured by varying degrees of autonomy and activities specialization. First, the organization as an autonomous cost centre is chosen for half of the UMs analysed, these representing the instances in which a higher specialization of activities and spending autonomy is recognized. Second, around a quarter of the UMs (23.5\%) is managed by a central administration unit, meaning that UMs are run directly by the university central staff, among a heterogeneous set of activities. Third, $11.8 \%$ of UMs represent service centres managing homogeneous activities, nevertheless without spending autonomy. A fourth model is found in $11.8 \%$ of UMs, where specific university departments are in charge of managing their collections. In such instances, UMs' activities are encompassed among the teaching and research ones that departments are deemed to carry out within a fair degree of spending autonomy. Finally, a residual model is found in a unique UM (2.9\%) that is managed by a distinct entity connected to the university (a foundation). Such variety of findings is consistent with the option to adopt the more suitable organizational model for managing university collections, provided by the ANVUR (Italian National 
Agency for the Evaluation of the University and Research System) pursuant Law 240/2010 (so called "Gelmini reform") which introduces managerial logics within the Italian HE systems (Tagliaventi et al., 2020; Veltri \& Puntillo, 2020).

A further result from the questionnaire pertains to the UMs' size, the latter has been investigated through the number of university staff units assigned to them. As shown in Table 2, the evidence is variegated in this respect, with around the $90 \%$ of UMs analysed placed in either the bigger or smaller size classes provided in the questionnaire. Accordingly, no more than three university staff units are assigned to $41.2 \%$ of UMs, whereas two groups of $7 \mathrm{UMs}$ each (together representing $41.2 \%$ ) are respectively managed by around 10-20 and more than 20 university staff units. It is worth adding that, as explicitly declared by one of the respondents, the size can depend on the stage of UMs' life, so that some UMs may have just started their activities and thus benefitting of less staff units. After all, university collection management has been recognized as relevant and valuable one within the Third Mission and Social Impact by the ANVUR since 2018 (https://www.anvur.it/wp- content/uploads/2018/11/SUA-TM_Lineeguida.pdf), thus boosting both human resources and financial investments from Italian universities only recently.

The last two questions of Section I provide insights on the accessibility to the UMs' collections - both in terms of opening hours and ticketing - which highlight the approach to public engagement developed by each UM within the Third Mission (Mozzoni et al., 2018). As for the former, results show that $20.6 \%$ of UMs is regularly opened during the whole week (with a usual day off), while $14.5 \%$ allow visitors to enjoy their collection just by appointment, in some cases to be scheduled on a precise week day. In between these two extremes, half of the UMs analysed follows the opening hours of any other university office, $11.8 \%$ declare to have a flexible opening hour (depending on collections) and just one of them is open 2 days per week (i.e., during weekends). As for the ticketing, most UMs (61.8\%) adopt a targeted fee entrance. Without making such distinction, $11.8 \%$ and $26.5 \%$ of UMs respectively allow a free entrance and require a fixed fee to make all categories of visitors enjoy their collections.

Turning to Sections II and III of the questionnaire, Figure 4 depicts a comparison between activities UMs were used to perform before (labelled as "pre-lockdown") and those that have been carried out during the COVID-19 lockdown (labelled as "lockdown"). The activities investigated through the questionnaire consist of both core and subsidiary activities that are typically managed by UMs. Enhancement of collections represents a core Third Mission activity, this consisting in exhibitions, workshops, conferences, and guided tours through which UMs transfer cultural knowledge to the community. Results highlight that $97 \%$ of UMs were engaged in performing core activities of that kind before the lockdown. As explained in the previous section, all those university activities that could have been realized by ensuring the social distancing have been allowed during the lockdown. As such, around $53 \%$ of the UMs analysed has resorted to video-telling as an alternative to in situ visits and $20 \%$ of them have managed to arrange videoconferences. Edutainment activities have been found to be performed by $79.4 \%$ of UMs in the pre-lockdown, thus highlighting how school students

- or broadly, younger students - are conceived as precious targets - among other community groups 
- of university knowledge transfer through UMs. Nevertheless, during the lockdown, almost $60 \%$ less has kept on carrying out edutainment activities ( $20.6 \%$ of UMs).

Not surprisingly, social media management - as a subsidiary type of activities - has not recorded variations among the two periods considered in the analysis (from $64.7 \%$ to $61.8 \%$ ), as it represents a communication channel through which UMs disseminate digital contents on the collections (Giannini \& Bowen, 2019). This result is corroborated by the evidence on promotional activities occurring through traditional communication media (e.g., local and national newspapers, broadcasting), which indeed decrease by $38.2 \%$ during the lockdown.

To gain further insights on the complex phenomenon under investigation, additional data from the questionnaire have been examined. Particularly, as sanctioned by the DPCM March 11th, the university lockdown has implied a shift towards distant learning and smart working. Coherently, $76.5 \%$ of the sample has adopted the latter solution to continue their activities. Moreover, it is remarkable that only $20 \%$ of them has invested in ICTs to respond to the lockdown disturbance.

Finally, results from Section IV provide a deeper understanding on UMs' role and activities during the lockdown from respondents' views (below numbered as they appeared in the research dataset). A common perspective is that the critical contingency experienced during the lockdown has promoted the enhancement of cultural values shared within a community. This has consequently strengthened the idea that UMs, by transferring cultural knowledge to the community, provide a public service with a relevant societal impact. As summarized in the following comment:

"Thanks to the time available [during the lockdown], art and culture have constituted not only a possibility for escape, but also an opportunity for individual and collective enhancement" (UM31).

As a matter of fact, the access to cultural content has been often ensured by UMs at distance, i.e. through digital technologies. Though this was already highlighted as a result from previous sections of the questionnaire, respondents' open answers stress how those technologies have enabled maintaining - or even attracting - UMs' visitors, by exploiting the recognized higher attention paid on cultural contents. Indeed, respondents declare that:

"[the lockdown] has increased the attention from the virtual audience, i.e. the one surfing the internet and social medias" (UM1).

And more broadly that:

"Ithe role of culture] may have increased thanks to the several digital initiatives UMs have been promoting for their visitors" (UM18).

As such, the level of digital engagement during the lockdown makes the following phases promising: 
"the approval rating of the activities carried out on social medias bodes a hope for our UMs' re-opening" (UM30).

Nevertheless, respondents share the idea that the digital technology is a conditio sine qua non but not sufficient for UMs to provide the desired societal impact, while the personal experience remains fundamental in this respect. Therefore, digital public engagement activities are perceived as temporary rather than permanent substitutes of on-site visits. To conclude this section, two specific respondents' quotes on this point reveal illuminating:

"The digital access [to cultural contents] during the lockdown period allowed to explore, discover and deepen the different opportunities in the area, as evidenced by the very high index of access to websites, and in particular to social media, museums and other cultural institutions in the country. Digital visits prelude, in most cases, to the on-site visit and constitute its preparation" (UM2).

"In times of crisis, cultural heritage certainly represents a reassuring refuge, as it refers to the reassuring identity of a community. The isolation from a pandemic certainly placed the emphasis on cultural content and values, too often taken for granted, and above all on the irreplaceable use of presence. The need now will be to find smart solutions not to make the virtual end in itself, but rather to boost its integration with emerging needs" (UM8).

\section{Discussion}

Findings of this paper have shed a light on the role played by Italian UMs within university Third Mission and on their resilience ability in responding to the COVID-19 disturbance. Results from the first two sections of the questionnaire have highlighted those key features and activities that enable Italian UMs to generate public value and societal impact through the transfer of cultural knowledge to the communities (Bozeman, 2000; Bozeman et al., 2013).

Research background analysis has stressed the social and economic impact that the COVID-19 has had in Italy, including the HE system. Occurring as an external, unexpected, and sudden disturbance for that community, the pandemic has represented a critical shock to cope with. Considering the anti- COVID-19 measures adopted by the Italian government (DPCM March 11th, 2020), this study has added new evidence on the university response concerning their Third Mission, with regard to UMs management. The COVID-19 disturbance has challenged the normal conditions through which Italian UMs transfer cultural knowledge. Results from the questionnaire highlight how UMs have resorted to digital-based solutions to provide that public service (Macfarlane, 2007). UMs' core activities have not been totally shut down, whereas video-telling and videoconferencing have been used to maintain a condition of normalcy, partially preserving the relationship with the community. Results additionally show that digital technologies have not been pervasive, insofar as communities' members that were not familiar with them may have met some barriers for accessing the UMs' contents. Similarly, the decrease in edutainment activities reveals that technology has not always supported the relationship with the extant audience (Giannini \& Bowen, 2019). The normalcy has also encompassed the social media management, as a 
subsidiary UMs' activity. Although promotion has shown a decrease during the lockdown, it is nevertheless carried out by more than a quarter of the sampled UMs.

All this considered and recalling the resilience notion adopted in this paper, Italian UMs have proved the ability to respond to the external disturbance by restoring a sense of normalcy during the lockdown through the digital technology (Agostino et al., 2020). Precisely, this study answers to the research question by arguing that Italian UMs have responded to the COVID-19 lockdown by showing a precursor type of resilience. Indeed, they have handled the ongoing disturbance by keeping their usual activities within a bandwidth conditions, in a way to prevent worse repercussions. This new normalcy condition exploits creativity and technology for cultural knowledge transfer to the community (Moreton, 2018). Nevertheless, the digital public engagement emerges as a means to maintain or increase the relationship with the community during the most severe moment of the emergency without for this substituting the on-site visits that are expected after the lockdown (Packer, 2008; Pegoraro \& Zan, 2017). This enables to depict a conceptual model on UMs resilience ability in times of emergency (Figure 5).

The contribution of the conceptual model is twofold. On the one hand, it sheds light on those activities that UMs are able to carry out to respond to an external disturbance such as the COVID-19, thus exploiting the creativity and technology already existing in those organizations. On the other hand, the model emphasises the role of UMs to the Third Mission resilience at time of emergency.

\section{Conclusion}

This study has presented a timely evidence on how universities have responded to the COVID-19 emergency, regarding their Third Mission. In so doing, a specific element of originality stems from the creation of a dataset on Italian UMs, which maps their distribution throughout the country as well as their demographics.

The research advances three contributions to the knowledge on HE systems. First, it promotes the investigation of UMs as key public service providers within the Third Mission of HE organizations, such as universities. Among the public engagement activities, UMs play as non-STEM subject that transfer cultural knowledge to the community, thus producing a relevant societal impact and taking part to the development of universities' Third Mission. To explore how Italian UMs have responded to the COVID-19 emergency, this study has resorted to the social science notion of resilience. In so doing, a second contribution arises from enlarging the understanding of resilience in the HE literature, where it had been adapted at the individual rather than organizational level. Third, by bridging the literature on HE Third Mission and emergency management, this research proposes a conceptual model on UMs' resilience, which depicts the activities they are able to carry out as a means to handle an ongoing external disturbance and ensure their contribution to the university Third Mission at time of emergency.

The role played by digital technologies during the lockdown - as tools of digital public engagement 
- paves the way to social implications connected to the accessibility of the cultural content proposed by UMs. Findings stress that the use of virtual contents is likely to sacrifice the engagement of some community targets, such as younger students and visitors not familiar with the digital technologies. Nevertheless, the conceptual model on UMs' resilience also encompasses "non-digital" activities (e.g., promotion through traditional medias) to address public value towards a general audience. As such, a practical implication of this investigation relies on suggesting university policy makers and managers (e.g., Deans, UMs' Presidents, Directors and Curators) to diversify the means of public engagement at time of emergency, in a way to ensure the inclusiveness of the public service they provide.

Finally, it must be remarked that this study focused on a single country and on a specific Third Mission activity. Moreover, the institutional point of view has been privileged as compared to the community one. Consequently, further research may explore both the digital audience satisfaction and the other nondigital targets' perception on the public service delivered by UMs during the lockdown. The single case study research methodology would be suitable to this aim, insofar as it can provide a more holistic interpretation of such a complex phenomenon, eventually grounding the conceptual model here proposed. Furthermore, cross-countries research may replicate this investigation, in order to extend the understanding of UMs' resilience in countries where the COVID- 19 has produced different social and economic impacts. Not least, future studies on the relationships between organizational UMs variables and their resilience ability against external disturbances are welcomed.

\section{Declarations}

\section{Statement on competing interests: The authors declare no competing interests.}

\section{References}

Agostino, D., Arnaboldi, M., \& Lampis, A. (2020). Italian state museums during the COVID-19 crisis: from onsite closure to online openness. Museum Management and Curatorship, O(0), $1-11$. https://doi.org/10.1080/09647775.2020.1790029

Alexander, D. E. (2013). Resilience and disaster risk reduction: An etymological journey. Natural Hazards and Earth System Sciences, 13(11), 2707-2716. https://doi.org/10.5194/nhess-13- 2707-2013

Barker, K. (2015). The challenging Australian policy context for university engagement. Journal of Higher Education Policy and Management, 37(5), 477-489.

Blühm, A. (2020). Groninger Museum. Museum Management and Curatorship, 1-2.

Boin, A., \& van Eeten, M. J. G. (2013). The Resilient Organization. Public Management Review, 15(3), 429-445. https://doi.org/10.1080/14719037.2013.769856 
Bozeman, B. (2000). Technology transfer and public policy: a review of research and theory. Research policy, 29(4-5), 627-655.

Bozeman, B., Fay, D., \& Slade, C. P. (2013). Research collaboration in universities and academic entrepreneurship: the-state-of-the-art. The journal of technology transfer, 38(1), 1-67.

Bruijne, M. de, Boin, A., \& van Eeten, M. (2010). Resilience: exploring the concept and its meanings.

Designing resilience: Preparing for extreme events, 13-32.

Bundy, J., Pfarrer, M. D., Short, C. E., \& Coombs, W. T. (2017). Crises and Crisis Management: Integration, Interpretation, and Research Development. In Journal of Management (Vol. 43, Numero 6). https://doi.org/10.1177/0149206316680030

Colasanti, N., Frondizi, R., \& Meneguzzo, M. (2018). Higher education and stakeholders' donations: successful civic crowdfunding in an Italian university. Public Money \& Management, 38(4), 281-288.

Comfort, L. K., Boin, A., \& Demchak, C. C. (2010). Designing resilience: Preparing for extreme events. University of Pittsburgh Pre.

Comfort, L., Kapucu, N., Ko, K., Menoni, S., \& Siciliano, M. (2020). Crisis Decision Making on a Global Scale: Transition from Cognition to Collective Action under Threat of COVID-19. Public Administration Review.

Conz, E., \& Magnani, G. (2020). A dynamic perspective on the resilience of firms: A systematic literature review and a framework for future research. European Management Journal, 38(3), 400-412.

Cotton, D. R. E., Nash, T., \& Kneale, P. (2017). Supporting the retention of non-traditional students in Higher Education using a resilience framework. European Educational Research Journal, 16(1), 62-79.

Cummings, W. K. (1998). The service university movement in the US: Searching for momentum. Higher Education, 35(1), 69-90.

Duit, A. (2016). Resilience thinking: Lessons for public administration. Public Administration, 94(2), 364380 .

Englund, H., Gerdin, J., \& Burns, J. (2011). 25 years of Giddens in accounting research: achievements, limitations and the future. Accounting, Organizations and Society, 36(8), 494-513.

Entress, R., Tyler, J., \& Sadiq, A. (2020). Managing Mass Fatalities during COVID-19: Lessons for Promoting Community Resilience During Global Pandemics. Public Administration Review.

Fligstein, N., \& Habinek, J. (2014). Sucker punched by the invisible hand: the world financial markets and the globalization of the US mortgage crisis. Socio-Economic Review, 12(4), 637-665. 
Foster, H. D. (1993). Resilience theory and system evaluation. In Verification and Validation of Complex Systems: Human Factors Issues (pagg. 35-60). Springer.

Geuna, A., \& Muscio, A. (2009). The governance of university knowledge transfer: A critical review of the literature. Minerva, 47(1), 93-114.

Giannini, T., \& Bowen, J. P. (2019). Museums and Digital Culture. Springer.

Gibson, C. A., \& Tarrant, M. (2010). A'conceptual models' approach to organisational resilience. Australian Journal of Emergency Management, The, 25(2), 6.

Giddens, A. (1981). Agency, institution, and time-space analysis. Advances in social theory and methodology. Toward an integration of micro-and macro-sociologies, 161-174.

Hu, Q., Knox, C. C., \& Kapucu, N. (2014). What have we learned since September 11, 2001? A network study of the Boston marathon bombings response. Public Administration Review, 74(6), 698-712.

Jing, Y. (2020). Marching through the deep-water zone: Chinese public sector reforms and the way forwards. Public Management Review, 1-8.

Knudsen, M. P., Frederiksen, M. H., \& Goduscheit, R. C. (2019). New forms of engagement in third mission activities: a multi-level university-centric approach. Innovation, 1-32.

Labaka, L., Hernantes, J., \& Sarriegi, J. M. (2016). A holistic framework for building critical infrastructure resilience. Technological Forecasting and Social Change, 103, 21-33.

https://doi.org/10.1016/j.techfore.2015.11.005

Linnenluecke, M., \& Griffiths, A. (2010). Beyond adaptation: Resilience for business in light of climate change and weather extremes. In Business and Society (Vol. 49, Numero 3).

https://doi.org/10.1177/0007650310368814

Macfarlane, B. (2007). Defining and rewarding academic citizenship: The implications for university promotions policy. Journal of Higher Education Policy and Management, 29(3), 261-273.

https://doi.org/10.1080/13600800701457863

Martin, B., \& Etzkowitz, H. (2000). The origin and evolution of the university species. Organisation of mode, 2.

Martin, C. R. (2015). Resilience: Paradoxical insight or conceptual poverty? Journal for Multicultural Education, 9(3), 117-121. https://doi.org/10.1108/JME-05-2015-0015

Moreton, S. (2018). Contributing to the creative economy imaginary: universities and the creative sector. In Cultural Trends (Vol. 27, Numero 5, pagg. 327-338). https://doi.org/10.1080/09548963.2018.1534575 
Mozzoni, I., Fanelli, S., \& Donelli, C. C. (2018). Italian university collections: managing the artistic heritage of the university's ivory tower. Journal of Cultural Management and Policy, 8, 30.

Nicolo', G., Manes-Rossi, F., Christiaens, J., \& Aversano, N. (2020). Accountability through intellectual capital disclosure in Italian Universities. In Journal of Management and Governance (Numero Parker 2011). Springer US. https://doi.org/10.1007/s10997-019-09497-7

Noordegraaf, M., \& Newman, J. (2011). Managing in disorderly times: How cities deal with disaster and restore social order. Public Management Review, 13(4), 513-538.

Ou, J. (2020). China Science and Technology Museum boosting fight against COVID-19. Museum Management and Curatorship, 1-6.

Packer, J. (2008). Beyond learning: Exploring visitors' perceptions of the value and benefits of museum experiences. Curator: The Museum Journal, 51(1), 33-54.

Parker, L. (2011). University corporatisation: Driving redefinition. Critical perspectives on accounting, 22(4), 434-450.

Pegoraro, M., \& Zan, L. (2017). Life and death in audience development. The exhibition on Pompeii at the British museum, 2013. Museum Management and Curatorship, 32(3), 210-231.

Perkmann, M., Tartari, V., McKelvey, M., Autio, E., Broström, A., D’Este, P., Fini, R., Geuna, A., Grimaldi, R., \& Hughes, A. (2013). Academic engagement and commercialisation: A review of the literature on university-industry relations. Research policy, 42(2), 423-442.

Pettersen, K. A., \& Schulman, P. R. (2019). Drift, adaptation, resilience and reliability: Toward an empirical clarification. Safety Science, 117, 460-468. https://doi.org/10.1016/j.ssci.2016.03.004

Potts, T. (2020). The J. Paul Getty Museum during the coronavirus crisis. Museum Management and Curatorship, 1-4.

Rapaccini, M., Saccani, N., Kowalkowski, C., Paiola, M., \& Adrodegari, F. (2020). Navigating disruptive crises through service-led growth: The impact of COVID-19 on Italian manufacturing firms. Industrial Marketing Management, 88, 225-237.

Sataøen, H. L. (2018). Transforming the "third mission" in Norwegian higher education institutions: a boundary object theory approach. Scandinavian Journal of Educational Research, 62(1), 52- 67.

Sciulli, N., D'Onza, G., \& Greco, G. (2015). Building a resilient local council: evidence from flood disasters in Italy. International Journal of Public Sector Management, 28(6), 430-448.

https://doi.org/10.1108/IJPSM-11-2014-0139 
Tagliaventi, M. R., Carli, G., \& Cutolo, D. (2019). Excellent researcher or good public servant? The interplay between research and academic citizenship. Higher Education, 1-22.

Tagliaventi, M. R., Carli, G., \& Cutolo, D. (2020). Excellent researcher or good public servant? The interplay between research and academic citizenship. Higher Education, 79(6), 1057-1078.

https://doi.org/10.1007/s10734-019-00456-7

Teng-Calleja, M., Hechanova, M. R. M., Sabile, P. R., \& Villasanta, A. P. V. P. (2020). Building organization and employee resilience in disaster contexts. International Journal of Workplace Health Management. https://doi.org/10.1108/IJWHM-09-2019-0122

Veltri, S., \& Puntillo, P. (2020). On intellectual capital management as an evaluation criterion for university managers: a case study. In Journal of Management and Governance(Vol. 24, Numero 1). Springer US. https://doi.org/10.1007/s10997-019-09461-5

Walker, C., Gleaves, A., \& Grey, J. (2006). Can students within higher education learn to be resilient and, educationally speaking, does it matter? Educational Studies, 32(3), 251-264.

Watermeyer, R., Crick, T., Knight, C., \& Goodall, J. (2020). COVID-19 and digital disruption in UK universities: afflictions and affordances of emergency online migration. Higher Education, 1.

Wellington, J. J., Bathmaker, A.-M., Hunt, C., McCulloch, G., \& Sikes, P. (2005). Succeeding with your Doctorate. Sage.

Wildavsky, A. (1988). Searching for safety transaction press. New Brunswick, NJ, USA.

Wright, S., \& Shore, C. (2017). Death of the Public University?: Uncertain Futures for Higher Education in the Knowledge Economy (Vol. 3). Berghahn Books.

Yin, R. K. (2017). Case study research and applications: Design and methods. Sage publications.

\section{Figures}




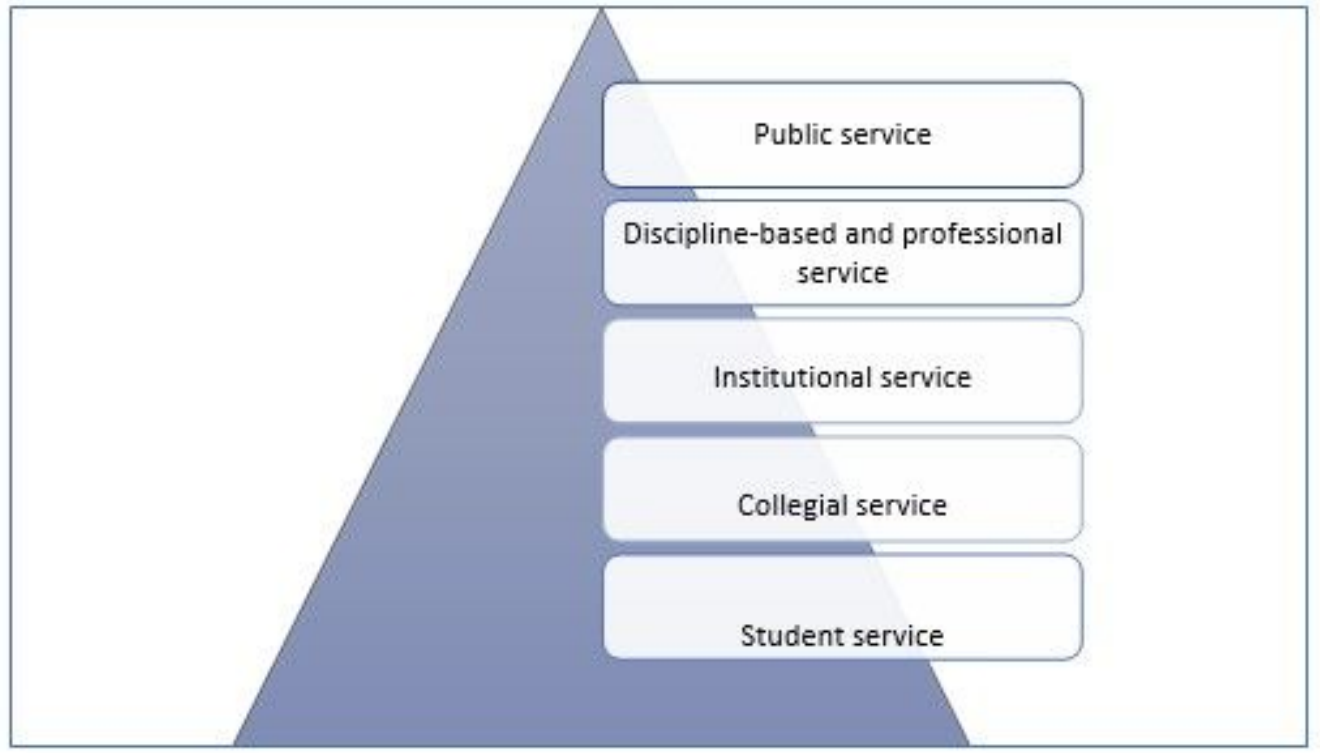

\section{Figure 1}

The Service Pyramid Model (Source: our adaption from Macfarlane, 2007: 265)

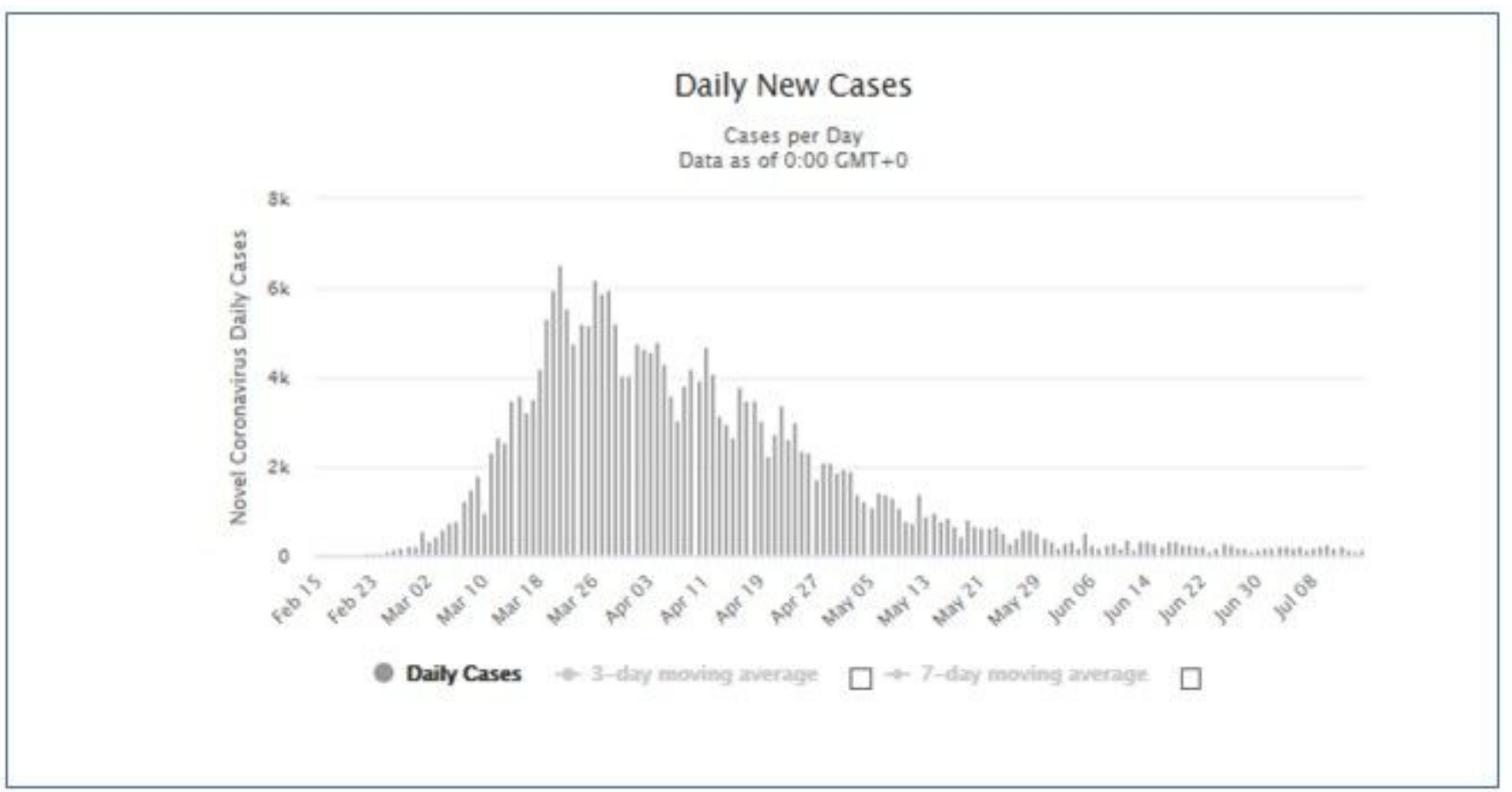

\section{Figure 2}

Daily New Cases in Italy (Source: https://www.worldometers.info/coronavirus/country/italy) 
DPCM February 23, 2020

O
DCPM May 17, 2020

$\mathrm{O}$

DPCM March 11, 2020

\section{Figure 3}

The research timeline (Source: authors' elaboration)

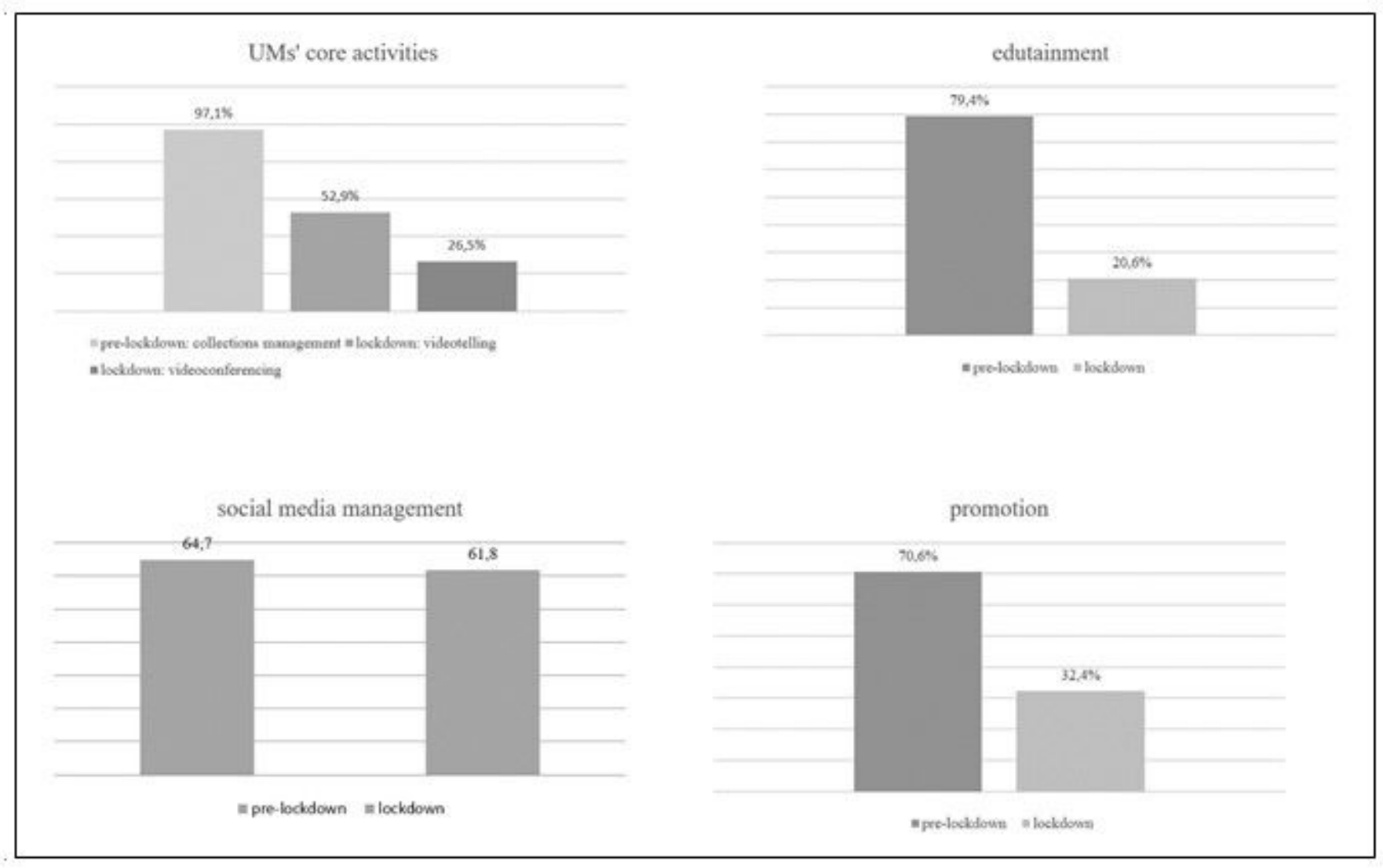

Figure 4

Research results from the questionnaire 


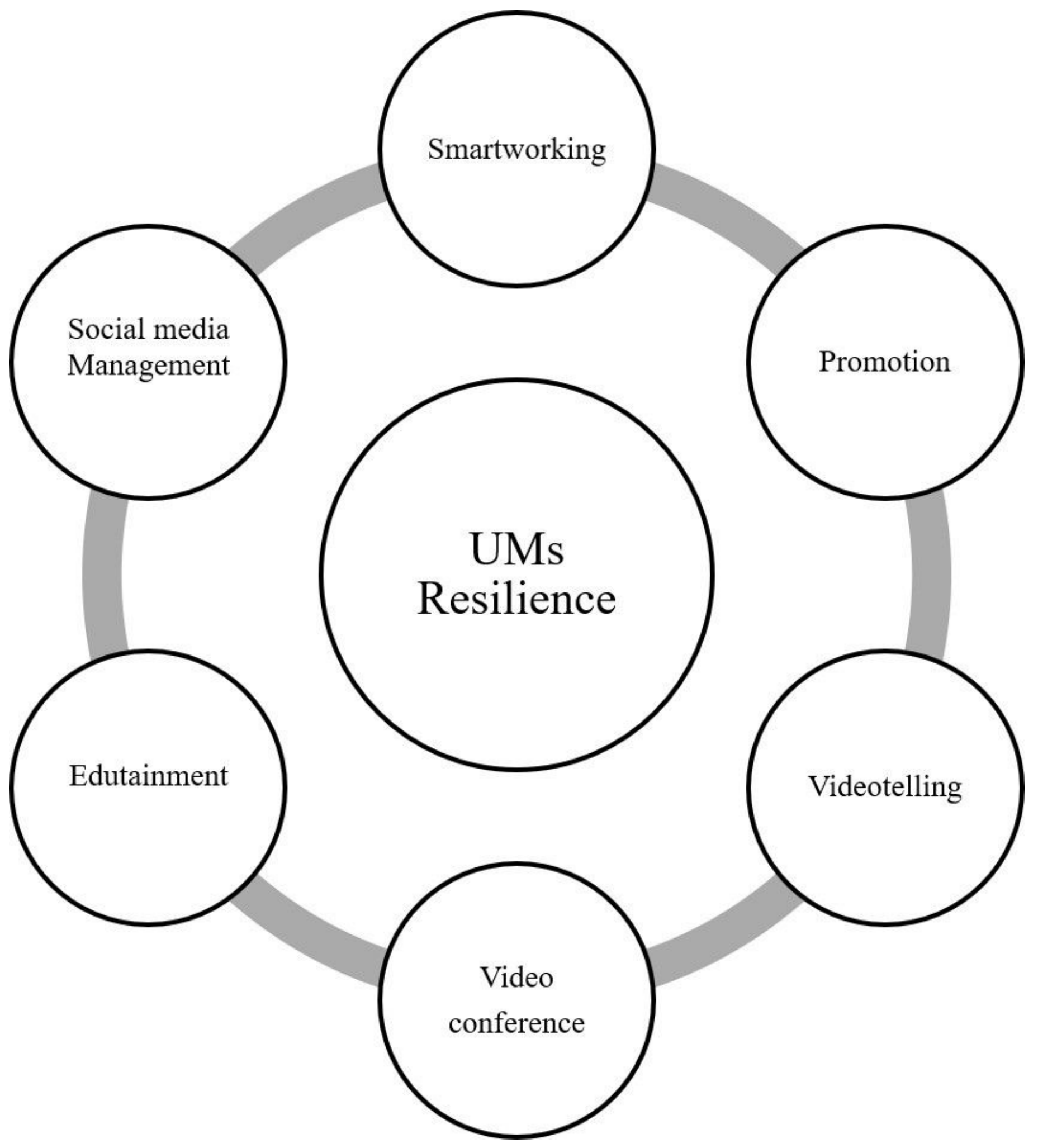

Figure 5

Conceptual model of UMs resilience 